\title{
Pelayaran Cheng Ho terhadap Pertukangan Cina pada Bangunan Masjid di Nusantara pada Abad ke-15M
}

\author{
Syaimak Ismail \\ Universiti Malaya, syaimakismail@gmail.com \\ Abdullah Yusof \\ Universiti Malaya, abdy@um.my \\ Wan Nurhafizah Mohd Shukri \\ Universiti Malaya,wan.nurhafizahms@gmail.com \\ Nabilah Mohd Razif \\ Universiti Malaya, mujahidahsolehah_87@yahoo.com
}

\begin{abstract}
Abstrak
Makalah ini menilai pengaruh dan kesan pertukangan Cina yang terdapat di Nusantara terutamanya yang dilihat di Jawa dan Melaka. Pengaruh ini bersandarkan kepada pelayaran Cheng Ho yang berlaku sekitar abad ke$15 \mathrm{M}$, telah membawa bersama keunikan reka bentuk dan seni bina Cina ke Nusantara. Berdasarkan kajian sejarah, Cheng Ho telah menjadikan pelayaran sebagai tunjang utama untuk mengukuhkan hubungan diplomatik di antara negara China dan negara yang dikunjungi oleh beliau. Hubungan ini dipanjangkan lagi dengan pertukaran budaya yang memberi manfaat kepada kedua belah pihak. Selain menjalankan usaha dakwah di setiap tempat yang dikunjungi, beliau tidak lupa untuk membangunkan masjid bagi kegunaan masyarakat tempatan. Hasil daripada hubungan yang terjalin telah memperlihatkan kekuatan hubungan diplomatik dan pertukaran budaya yang memberi impak positif kepada negara kunjungan.
\end{abstract}

Kata kunci: pertukangan, Cina, masjid, Nusantara, pelayaran Cheng Ho

\section{The Influence of Cheng Ho Voyage towards Chinese Carpentry on Mosques in the Malay Archipelago in the 15th Century AD}

\footnotetext{
Abstract

This article evaluates the influence and impact of Chinese carpentry in the Malay archipelago which particularly can be seen in Java and Malacca. Cheng Ho voyage that took place around in 15th century has brought together the unique architecture and design of Chinese architecture to the archipelago. Based on the study of history, Cheng Ho has made the voyage as a key pillar to strengthen diplomatic relations
} 
between China and the countries visited, and this relationship is extended further with cultural exchange that benefits both parties. In addition to missionary efforts in the locations visited, he did not forget to build a mosque for the use of the local. As a result of the relationship has demonstrated the strength of diplomatic relations and cultural exchange had a positive impact on the state visits. Revise accordingly, this paper is to evaluate the influence and impacts of the Chinese trade in the Archipelago are mainly seen in Java and Malacca.

Keywords: carpentry, Chinese, mosque, Malay archipelago, voyage of Cheng Ho

\section{Pendahuluan}

Pembangunan masjid di Melaka telah mengalami beberapa fasa yang memperlihatkan perkembangan binaan masjid iaitu fasa pemerintahan Kesultanan Melayu Melaka, jajahan Portugis dan Belanda. Sebaik sahaja Islam berada di puncak kegemilanganya, pembangunan masjid menjadi pesat dan sebuah kawasan yang dihuni ramai masyarakat Islam akan dianggap pelik sekiranya tidak terdapat masjid atau surau di kawasan berkenaan. Apabila fasa penjajahan Portugis merampas pentadbiran negara, masyarakat Islam dilarang mengamalkan agama dan pembinaan masjid tidak dibenarkan bahkan masjid-masjid yang dibangunkan sebelum penjajahan Portugis telah dimusnahkan kesemuanya tanpa ada satu pun yang ditinggalkan. Keadaan menjadi lebih baik apabila Belanda mentadbir dan memberikan kebenaran untuk masyarakat Islam mengamalkan ajaran agama dan memiliki masjid.

Masjid-masjid yang terdapat di Jawa mempunyai persamaan ketara dengan masjid di Melaka. Pengaruh pertukangan Cina lebih jelas dapat dilihat di Jawa sejak daripada abad ke-15 M lagi, dan masih bertahan sehingga ke hari ini. Hal ini kerana, penjajah Belanda lebih bersifat terbuka dalam mengamalkan ajaran agama. Penjajah Belanda yang mentadbir negara itu tidak pernah memusnahkan masjid di Jawa. Oleh yang demikian, masjid-masjid ini terpelihara bahkan rekod berkenaan masjid di Jawa lengkap dengan sejarah pembinaan dan asal usulnya. Berbeza daripada masjid-masjid yang terdapat di Melaka yang telah dimusnahkan tanpa ada satu pun yang ditinggalkan bahkan segala rekod berkenaan masjid telah dimusnahkan dengan tujuan untuk 
menghapuskan pengaruh agama Islam di Melaka. Masjid-masjid yang terdapat di Melaka dan Jawa mempunyai keistimewaannya yang tersendiri. Keunikan masjid ini memperlihatkan kemasukan pengaruh Cina yang mempunyai reka bentuk dan motif yang menarik sebagai ornamen utama. Kemasukan pengaruh Cina dalam seni bina masjid di Melaka dan Jawa bermula pada abad ke$15 \mathrm{M}$, melalui usaha Cheng Ho sewaktu pelayaran beliau dan imigran Cina ke Nusantara. Melalui kemasukan ini, unsur reka bentuk dari China ini telah meresap ke dalam binaan masjid di Melaka dan menjadi simbol keagungan Islam di negeri itu.

\section{Latar Belakang Cheng Ho}

Nama Islam Cheng Ho adalah Kasim San Bao. Dilahirkan pada tahun 1371 di daerah Kunyang, Yunnan. Beliau merupakan seorang Muslim yang berasal daripada keturunan Hui iaitu salah satu bangsa minoriti di China. Selain digelar sebagai Zheng He, beliau juga dikenali sebagai Sam Po yang diambil daripada dialek Fujian atau San Bao dalam bahasa nasional China. Cheng Ho juga adalah cicit kepada Shams al-Dīn Omar seorang berketurunan Parsi yang berhijrah ke China dan berkhidmat sebagai gabenor sewaktu zaman pemerintahan Dinasti Yuan. Beliau merupakan seorang Muslim yang taat serta berperanan dalam mengembangkan penyebaran Islam di China dan negara luar. ${ }^{1}$ Sewaktu beliau memegang jawatan sebagai laksamana, Cheng Ho dikatakan pernah berkhidmat di bawah tiga orang Maharaja Ming iaitu Maharaja Yung Lo (1402-1424), Maharaja Hung-Hsi (14241426 M) dan Maharaja Hsuan Te (1426-1433 M). ${ }^{2}$

\section{Ekspedisi Pelayaran Cheng Ho (1403-1433 M)}

Sejak 1405 M sehinggalah 1433 M, Laksamana Cheng Ho telah belayar sebanyak tujuh kali. Ekspedisi ini dikatakan berlaku pada 1405-1407 M, 1407-1409 M, 1410-1412 M, 1413-1415 M, 14171419 M, 1421-1422 M dan pelayaran terakhir berlaku pada 1431-

1 Kong Yuanzhi, Pelayaran Zheng He dan Alam Melayu (Bangi: Penerbit Universiti Kebangsaan Malaysia, 2000), 29-31.

2 Buyong Adil, The History of Mallaca: During the Period of the Malay Sultanate (Kuala Lumpur: Dewan Bahasa dan Pustaka, 1974), 8-26. 
$1433 \mathrm{M}^{3}$ Beliau juga dikatakan telah mengunjungi 37 buah negara $^{4}$ dan banyak pelabuhan yang telah disinggahi beliau termasuklah Samudera Hindia, Sri Langka, Quiloh, Kocin, Kalikut, Ormuz, Jeddah, Mugadisco dan Malindi. ${ }^{5}$ Sepanjang perjalanan dan ekspedisi yang dilakukan ini, mereka akan membawa pulang segala maklumat berharga berkaitan dengan keadaan laut, perjalanan sepanjang pelayaran, keadaan pelabuhan dan budaya asing dari tempat yang dikunjungi. Catatan yang dibuat juga adalah lengkap dan teratur. ${ }^{6}$

Peta 1: Peta Menunjukkan Perjalanan dan Pelayaran Cheng Ho yang Pernah dilakukan Sepanjang Tujuh Ekspedisi Beliau.

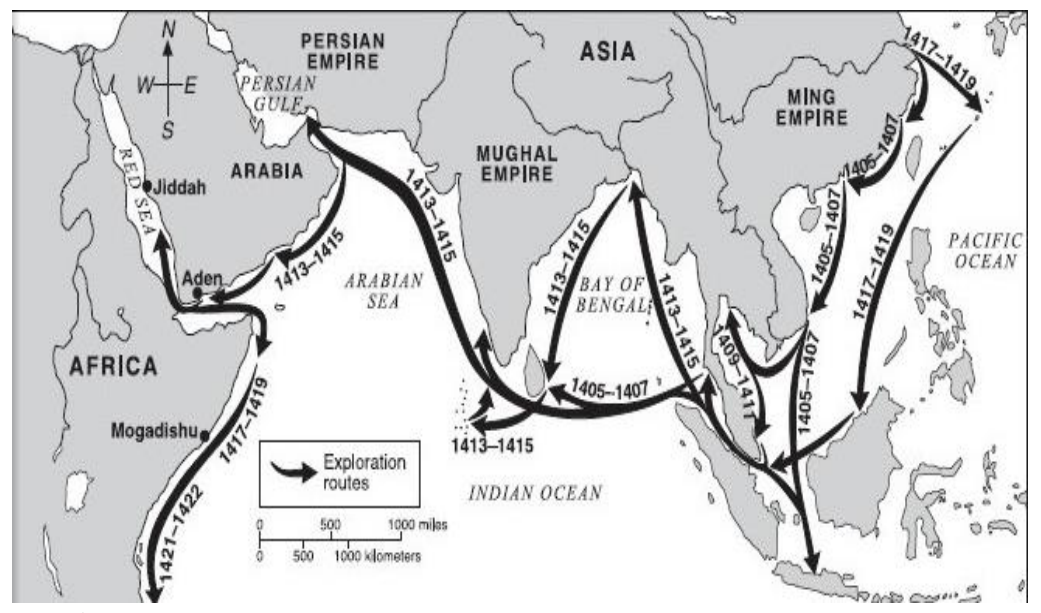

Sumber:

http://jelajaharchipelago.blogspot.com/2012/12/ekspedisipenjelajah-dunia.html

Dalam peta pelayaran beliau juga ada dicatatkan nama-nama tempat yang telah dikunjungi seperti Melaka, Pulau Pinang, Pulau Langkawi, Terengganu, Pahang, Kedah, Kelantan, Klang Gunung

3 Paul Wheatley, The Golden Khersonese (Kuala Lumpur: Penerbit Universiti Malaya, 2010), 88.

4 W.P. Groeneveldt, Notes on the Malay Archipelago and Mallaca Compilled from Chinese Sources (Jakarta: C.V. Bhratara, 1876), 44.

5 Kong Yuanzhi, Pelayaran Zheng He dan Alam Melayu, 85.

6 L. Carrington Goodrich, A Short History of the Chinese People (Britain: Allen \& Unwin, 1957), 194. 
Sembilan (di luar Sungai Perak), Pulau Tenggol (di antara Terengganu dan Pahang), Gunung Banang (di Selat Melaka), Pulau Jarak, Pulau Aur dan bahagian utara Pulau Kalimantan iaitu lokasi Sabah dan Sarawak kini. $^{7}$ Menurut catatan China terjemahan W.P. Groeneveldt, Cheng Ho juga pernah mengunjungi Champa , Java, Cambodja, Kukang, Siam, Calicut, Malakka, Broenei, Sumatra, Aru, Cochin, Great Coilan, Little Coilan, Soli, Western Soli, Cail, A-po-pa-tan, Co,ari, Ceylon, Lambri, Pahang, Kalantan, Hormus, Pi-la, The Maldive island, Sun-la, Magadoxu, Ma-lin-la-sah, Dsaffar, Sa-li-wa-ni, Jubo, Bengal, Arabia, Li-tai dan Nakur. Dalam catatan China, kebanyakan nama-nama negeri ini ditulis dalam bahasa China dan bacaannya agak menyimpang daripada bunyinya yang asal. Negeri Du Yuan yang tercatat dalam sejarah yang kemudiannya disebut Qu Du Kun atau Qu Du Quan sebenarnya adalah Dungun yang mana lokasinya terletak di Pantai Timur Semenanjung Tanah Melayu. ${ }^{8}$

Pelayaran yang dilaksanakan oleh Cheng Ho telah memberikan impak yang besar kepada kerajaan China dan negaranegara yang telah dikunjungi. Hubungan yang terjalin juga bukan berbentuk penaklukan tetapi lebih kepada persahabatan dan tidak terdapat sebarang bentuk kekejaman dalam proses tersebut bahkan berlaku proses pertukaran budaya dan adat di antara kedua-dua negara. Setiap negara yang dikunjungi mendapat hasil daripada sudut perniagaan dan perlindungan. China juga menjadi negara yang terkenal dan dihormati negara luar bahkan sentiasa mendapat tindak balas yang baik dalam apa jua bentuk urusan termasuklah perdagangan. ${ }^{9}$

${ }^{7}$ Liang Liji, Hubungan Empayar Melaka-Dinasti Ming Abad ke 15 (Bangi: Penerbit Universiti Kebangsaan Malaysia, 2009), 57.

${ }^{8}$ Liang Liji, "Jejak Langkah Sejarah Hubungan Persahabatan dan Diplomasi antara Melaka dan China, Kajian Komparatif Berdasarkan Karya Agung Melayu Sulalat al-Salatin dan Kitab-kitab Sejarah Lama China” (makalah, Karya Agung Melayu Sulalat al-Salatin dan Hikayat Hang Tuah, Persidangan Antarabangsa, Institut Kajian Sejarah dan Patriotisme Malaysia, Melaka, 2011), 14.

9 Liang Liji, "Jejak Langkah Sejarah Hubungan Persahabatan dan Diplomasi antara Melaka dan China, 120. 


\section{Penyebaran Dakwah oleh Cheng Ho}

Jika ditinjau kembali tentang peranan Laksamana Cheng Ho yang merupakan armada laut yang hebat, beliau juga adalah seorang Muslim yang taat pada perintah agama iaitu ajaran yang dibawa oleh Nabi Muhammad SAW. ${ }^{10}$ Beliau dikatakan sering kali menyebarkan ajaran Islam di China mahupun di negara-negara asing. Sewaktu ekspedisi Cheng Ho di bawah pemerintahan Maharaja Yung Lo Dinasti Ming, hampir sebahagian daripada anak kapal adalah beragama Islam. Antaranya ialah Ma Huan, Hasan, Wang Ching Hung, Kung Wu Ping, Fei Shin dan ramai lagi tokoh Muslim yang taat dengan ajaran Islam. ${ }^{11}$ Ekspedisi yang dipimpin oleh Cheng Ho ini bukan atas dasar ekonomi dan politik semata-mata, bahkan beliau mempunyai agendanya yang tersendiri dalam dakwah Islamiah. ${ }^{12}$ Dalam setiap pelayaran beliau, Cheng Ho tidak pernah lupa akan tanggungjawabnya untuk menyebarkan dakwah Islam ke setiap tempat yang dikunjungi oleh beliau. ${ }^{13}$ Antara tempat tersebut ialah Semarang atau Gedung Batu iaitu pada awal abad ke-15 M. Gedung Batu dikatakan pernah menjadi pusat kepada penyebaran Islam zaman dahulu kala. Melalui ekspedisi maritim yang bermula sekitar abad ke-13 M ini, golongan peniaga yang terdiri daripada kalangan orang Cina turut serta dalam aktiviti dakwah dan penyebaran Islam kepada masyarakat setempat di Nusantara seperti Palembang dan Gerisik. ${ }^{14}$

${ }^{10}$ Kong Yuanzhi, Pelayaran Zheng He dan Alam Melayu, 106-107.

${ }^{11}$ Sumanto al-Qurtuby, Arus-Cina-Islam-Jawa (Jogjakarta: Inspeal Ahimsakarya Press, 2003), 43.

12 Sumanto al-Qurtuby, Arus-Cina-Islam-Jawa, 43.

${ }^{13}$ Kejayaan cemerlang yang dicapai oleh Cheng Ho bukan sahaja ditentukan oleh faktor ketenteraanya tetapi juga disebabkan oleh identiti beliau sebagai seorang Muslim. Indentitinya sebagai Muslim telah berjaya mencipta jaringan Muslim di persisir Samudera Hindia yang kukuh pada ketika itu sama ada dalam dunia perdagangan atau politik. Hal ini kerana pada waktu misi pelayaran tersebut, agama Islam telah menguasai hampir setiap kawasan perdagangan. Oleh itu, misi ini memudahkan serta dapat membantu Cheng Ho bagi mencapai setiap kejayaan dalam misi pelayaranya. Sila lihat Sumanto al-Qurtuby, Arus CinaIslam-Jawa, 88.

${ }^{14}$ H.J. de Graaf dan Th. G. Th. Pigeaud, Cina Muslim: di Jawa Abad xv dan xvi antara Historisitas dan Mitos, ed. M.C Ricklefs (Jakarta: PT. Tiara Wacana Yogya, 1998), 2-3. 
Cheng Ho juga tidak pernah ketinggalan untuk menempatkan para pendakwah di setiap negara yang disinggahi beliau. Tugastugas mereka adalah untuk menyebarkan dakwah Islamiah demi kepentingan Islam dan kerajaan Dinasti Ming. ${ }^{15}$ Golongan peniaga Cina ini boleh diibarat "sambil menyelam sambil minum air" yang mana mereka menjalankan aktiviti perniagaan sambil menjalankan dakwah Islamiah. ${ }^{16}$ Pada ketika ini dikatakan armada Cina yang berada di bawah pimpinan Cheng Ho telah berjaya menguasai perairan dan pantai-pantai di sekitar Asia Tenggara. Hasil daripada penguasaan tersebut masyarakat Cina Muslim yang bermazhab Hanafi telah membentuk penempatan mereka sendiri seperti yang terdapat di Semenanjung Malaya, Pulau Jawa dan Filipina dan di kawasan penempatan itu jugalah para pengikut Cheng Ho telah mendirikan masjid bagi kegunaan masyarakat Islam di sana. ${ }^{17}$

\section{Peranan Cheng Ho dalam Pembangunan Masjid di Nusantara}

Di setiap persinggahan Cheng Ho, banyak masjid yang dibangunkan di Nusantara terutamanya di Jawa seperti Masjid Mercusuar di Cirebon, Masjid Kali Angke Masjid Tamien Dosol Seeng dan Masjid Nyonya Cai yang terletak di Jakarta. ${ }^{18}$ Masjid yang turut dipengaruhi seni pertukangan Cina juga adalah Masjid Agung Demak, Masjid Kudus dan Masjid Mantingan yang terletak di Semarang. Salah sebuah masjid yang masih wujud dan kekal reka bentuknya sehingga ke hari ini ialah Masjid Agung Demak yang dibangunkan pada awal abad ke-15 M. ${ }^{19}$ Masjid ini terletak di pantai Utara Jawa dan merupakan pusat perkembangan Islam yang tertua di kepulauan Melayu. Pembinaan masjid ini berlaku sewaktu di bawah pemerintahan Raden Patah setelah berjaya menumbangkan kerajaan Majapahit dan mendirikan kerajaan

${ }^{15}$ Sumanto al-Qurtuby, Arus Cina-Islam-Jawa, 86.

16 Teo Kok Seong, "Bukti dan Pengaruh Cina Muslim di Nusantara" (makalah, Seminar Sumbangan Orang Cina Terhadap Perkembangan Islam di Nusantara, Peringkat Kebangsaan, 24-26 Ogos 2006), 4.

${ }^{17}$ Kong Yuanzhi, Muslim Tionghoa Cheng Ho: Misteri Perjalanan Muhibah di Nusantara (Jakarta: Pustaka Populer Obor, 2000), 114.

${ }^{18}$ Sumanto-al-Qurtuby, Arus Cina Islam Jawa, 43.

${ }^{19}$ H.J. de Graaf dan Th. G. Th. Pigeaud, Chinese Muslims in Java in the 15th and 16th centuries: the Malay Annals of Semarang and Cerbon, ed. M.C Ricklefs (Melbourne: Monash University, 1984), 27. 
Islam Demak. ${ }^{20}$ Kejayaan mendirikan kerajaan Islam Demak disusuli dengan pembangunan lambang kemegahan Islam iaitu sebuah masjid. Tukang yang bertanggungjawab bagi pembinaan masjid Agung Demak adalah seorang Muslim yang berbangsa Cina yang bernama Gan See Chang, ${ }^{21}$ merupakan seorang mandur di dalam kapal Cheng Ho yang bergerak ke Semarang. ${ }^{22}$

\section{Gambar 1: Masjid Agung Demak yang dibangunkan di Semarang} pada awal abad ke-15 M

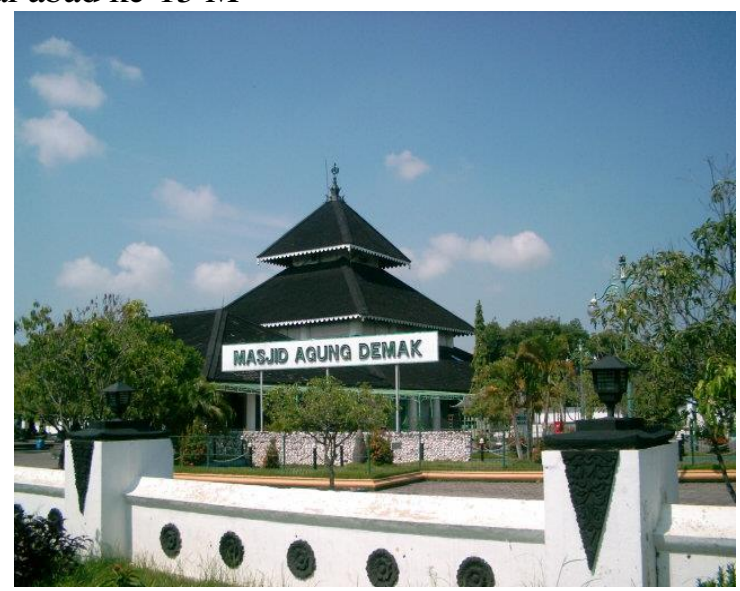

${ }^{20}$ Sumanto al-Qurtuby, Arus Cina Islam Jawa (Jogjakarta: Inspeal Ahimsakarya, 2003), 117-118.

${ }^{21}$ Atas permintaan Jin Bun (Raden Patah), Gan See Chang telah melakar dan membina masjid Agung Demak dengan bantuan anak-anak kapal yang ikut sama belayar. Masjid ini dibina oleh tukang-tukang kayu yang mahir serta bertanggungjawab membaiki sebarang kerosakan kayu di dalam kapal Cheng Ho. Kekuatan tiang besar "soko tatal" yang terdapat di dalam masjid Agung Demak ini adalah serupa dengan kekuatan kayu yang boleh dilihat pada kapalkapal kerajaan Dinasti Ming. Sila lihat H.J. de Graaf, Th. G. Th. Pigeaud, Chinese Muslims in Java in the 15th and 16th centuries: the Malay Annals of Semarang and Cerbon, 28-29.

22 Slametmuljana, A Story of Majapahit (Singapore: Singapore University Press, 1976), 247. Lihat juga S Vlatseas, A History of Malaysian Architecture (Singapore: Longman Singapore Publisher, 1990), 43. 
Terdapat pandangan yang mengatakan bahawa lambang kurakura $^{23}$ yang terdapat pada mihrab masjid ini diimport dari China sewaktu kegemilangan Dinasti Ming. Jika pandangan ini benar, ia menunjukkan pengaruh pertukangan Cina dalam pembinaan masjid di Nusantara adalah jelas. Selain itu, lambang kura-kura tidak pernah diguna pakai oleh masyarakat di Nusantara pada ketika itu. Penggunaan motif kura-kura pada bahagian mihrab ini merupakan simbol kepada kemenangan kerajaan Demak yang berjaya menggulingkan kerajaan Majapahit pada awal abad ke-15 M. Pada waktu tersebut, Jawa dan China mempunyai hubungan yang erat. Kerajaan China pada kala tersebut dikuasai oleh Dinasti Ming $^{24}$ dan maharaja negara China pada ketika ini adalah seorang Muslim Cina yang berpegang dengan mazhab Hanafi. ${ }^{25}$

Gambar 3: Lambang Kura-kura pada Mihrab Masjid Agung Demak

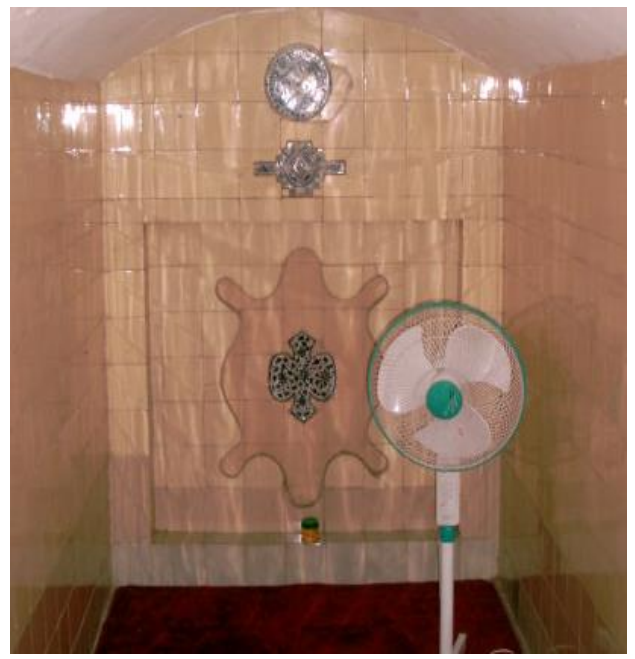

${ }^{23}$ Lambang kura-kura adalah merupakan lambang utama kepada pemerintahan Dinasti Ming. Makna simbolik bagi kura-kura adalah usia yang panjang. Ini kerana haiwan ini mempunyai usia yang panjang dan boleh hidup dalam tempoh yang lama. Sehubungan dengan itu, penggunaan kura-kura sebagai lambang kerajaan adalah sebagai harapan agar kerajaan itu dapat bertahan lama serta pentadbiranya kekal dalam keadaan yang baik.

${ }^{24}$ Sumanto al-Qurtuby, Arus Cina Islam Jawa, 117-118.

${ }^{25}$ H.J. de Graaf dan Th. G. Th. Pigeaud, Chinese Muslims in Java in the 15th and 16th centuries: the Malay Annals of Semarang and Cerbon, 13. 
Peranan masyarakat Cina di dalam pertukangan masjid ini ada juga disebut oleh H.J. de Graaf dan Pigeaud dalam Sejarah Melayu Semarang dan Ceribon;

"The Malay annals contain intresting information on the building of mosque by spreading Islamic Chinese communities in the archipelago. The style of these Chinese mosque cannot have been different from the pagodas used in China for religious purpose by all denominations, which are characterized by a number of superimposed roofs. The Malay tale concerning the changing of Chinese mosque into temples is evidence for the inherent association of this style with religion, irrespective of denomination. The Malay annal information on the part taken by non-Muslim Chinese of Semarang in the building of the first great mosque in Demak 1470 confirm the hypothesis of the Chinese origin of the dynasty of Demak cannot be doubted. As Chinese communities we established in the archipelago, the pagoda style of mosque had an opportunity to spread widely.

Keunikan pembinaan masjid yang menerima pengaruh Cina ini dikembangkan secara meluas oleh masyarakat Cina yang berhijrah ke Kepulauan Melayu. Masjid yang terdapat kesan seni bina Cina ini dilihat mempunyai persamaan dengan pagoda yang diterdapatcdi China untuk aktiviti keagamaan dan dikelaskan mengikut tindihan susunan bumbung. Antara pengaruh Cina yang boleh dilihat pada masjid ini adalah seperti penggunaan jubin Cina dan dinding bata Cina. Selain itu, pengaruh Cina juga dapat dilihat pada ukiran dan dinding plak yang dicat serta ukiran cina yang menarik pada mimbar, dinding, pintu gerbang dan tembok batu masjid yang banyak dipengaruhi ajaran Buddha. ${ }^{27}$ Tujuh pelayaran yang diketuai oleh Cheng Ho atas arahan daripada kerajaan Dinasti Ming menjadikannya sebagai teori yang kukuh bahawa reka bentuk masjid berbumbung meru ini didatangkan khas dari China. Menara berbentuk pagoda dan sulur bayur pada bucu bumbung masjid dan ukiran menarik pada masjid antara bukti

${ }^{26}$ H.J. de Graaf dan Th. G. Th. Pigeaud, Chinese Muslims in Java in the 15th and 16th centuries: the Malay Annals of Semarang and Cerbon, 179-180.

${ }^{27}$ Bruce Allan, "Notes on Early Mosques of The Malaysian Peninsula," Journal of the Malaysian Branch of the Royal Asiatic Society 69, part 2, no. 271 (1996), 77. 
kukuh seni bina masjid ini menerima pengaruh dari China. ${ }^{28}$ Menurut Ken Yeang, ciri-ciri khas yang terdapat pada masjidmasjid di Melaka ini bukan berasal daripada Arab tetapi lebih menyerupai bentuk bangunan yang terdapat di negara China. Masjid-masjid ini juga menjadi identiti kepada pembentukan masjid yang terdapat di Nusantara. ${ }^{29}$ Sepanjang kajian lapangan dilakukan, ciri-ciri khas yang terdapat di masjid berbumbung meru yang terdapat di Nusantara mempunyai persamaan dengan bangunan kediaman, rumah ibadat dan masjid-masjid di negara China. Komponen-komponen seperti sulur bayur, mahkota atap dan bangunan berbumbung meru yang hanya didapati di Nusantara dan China sahaja. ${ }^{30}$ Kawasan selatan negara China adalah lokasi yang banyak memberikan kesan kepada pembentukan seni bina China di Nusantara kerana mereka di antara kelompok yang banyak berhijrah keluar dari tempat asal mereka terutamanya dari wilayah Fukien dan Canton. ${ }^{31}$

Rajah 1: Masjid Berbumbung Meru iaitu Masjid Kg. Keling, Melaka

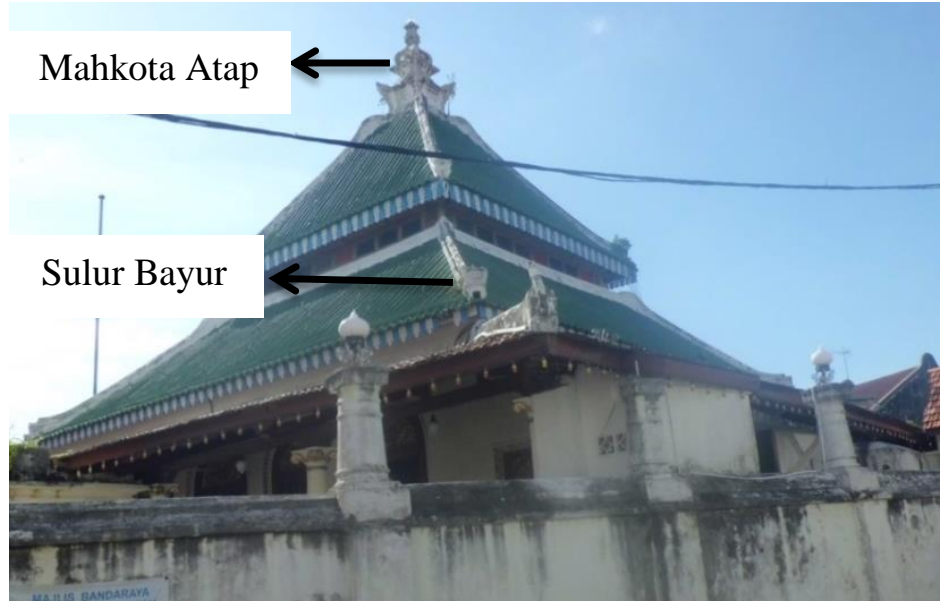

${ }^{28}$ Ta Ta Sen, Cheng Ho and Islam in Southeast Asia (Singapore: ISEAS Publishing Institute of Southean Asian Study, 2009), 198-202.

${ }^{29}$ Ken Yeang, Architecture of Malaysia (Kuala Lumpur: Pepin Press, 1992), 119.

${ }^{30} \mathrm{~S}$ Vlatseas, a History of Malaysian Architecture, 46.

${ }^{31}$ David G Kohl, Chinese Architecture in the Strait Settlements and Western Malaya (Hong Kong: University of Hong Kong, 1978), 82. 
Rajah 2: Masjid Xian, China Berbumbung Tiga Lapis

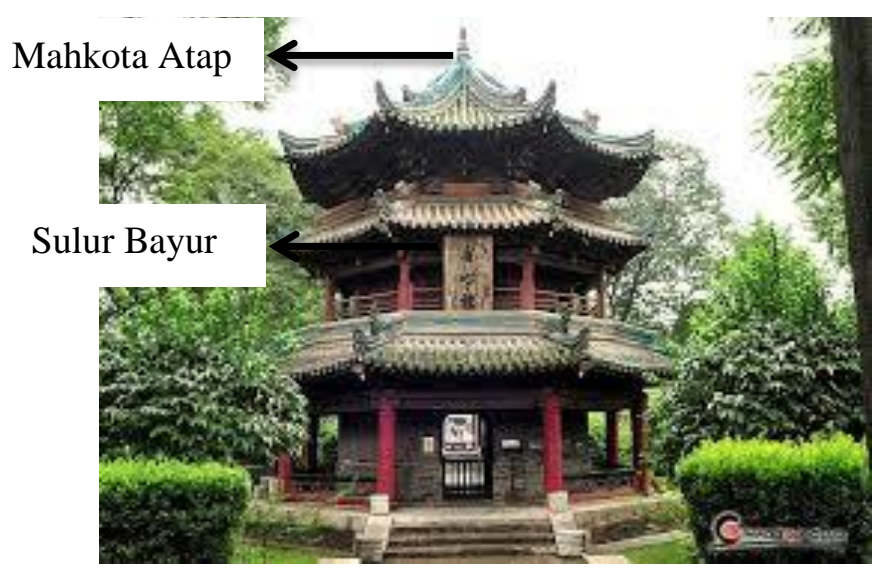

Pembangunan masjid di Melaka berlaku sebaik sahaja Parameswara atau Sultan Iskandar Syah memeluk agama Islam. ${ }^{32}$ Seiring dengan itu, reka bentuk Cina mula diperkenalkan apabila Melaka menjalinkan hubungan diplomatik dengan kerajaan China melalui perantaraan Cheng Ho. Sewaktu lawatan pertama Sultan Melaka iaitu Parameswara ke China (1411M), kerajaan China telah menghadiahkan beberapa tukang Cina yang beragama Islam dan sekembalinya mereka ke Melaka bangunan-bangunan masjid mula didirikan. ${ }^{33}$ Selain itu, perkembangan reka bentuk masjid berunsur Cina ini juga berlaku melalui masyarakat Cina yang menetap di Melaka. Hubungan baik yang terjalin di antara keduadua belah pihak ini telah menggalakkan orang Cina untuk menetap di negeri Melaka, akhirnya lahir masyarakat yang dikenali sebagai "Cina Baba" atau "Cina peranakan." 34 Kemahiran pertukangan

32 Armando Cortesao, The Suma Oriental of Tom Pires (London: Haklyut Society, 1944), 241. Lihat juga Amelia Fauzia, Faith and the State: a History of Islamic Philantrophy in Indonesia (Indonesia: Bill's Southeast Asia Library), 68.

${ }^{33}$ Hamka, Sejarah Umat Islam (Kuala Lumpur: Pustaka Antara, 1980), 447.

${ }^{34}$ Masyarakat peranakan Cina adalah komuniti kahwin campur yang mana mereka beribukan orang Melayu. Mereka juga memperlihatkan cara hidup yang lebih mirip kepada kehidupan cara orang Melayu sendiri di samping turut mengamalkan budaya dan adat Cina. Sila lihat Victor Purcell, The Chinese in Malaya (London: Oxford University, 1967), 61. Agama asal kebanyakan 
China yang ada pada tukang-tukang yang terdiri daripada Cina peranakan ini turut mempengaruhi kaedah pembinaan dan seni bina asli di Melaka. ${ }^{35}$ Oleh sebab itu, banyak masjid-masjid di Melaka yang mempunyai bentuk dan pengaruh dari China. ${ }^{36}$

Menurut Tom Pires, masjid-masjid di Melaka terutamanya masjid Kesultanan Melayu Melaka yang terletak berhampiran dengan istana sultan adalah merupakan masjid yang terkenal dan diketahui di seluruh dunia dan mempunyai persamaan dengan masjid Agung Demak. ${ }^{37}$ Prototaip binaan Masjid Agung Demak ini telah diperkenalkan kepada Melaka sekitar abad ke-15 M dan reka bentuk tersebut telah berkembang luas sehingga ke perairan Pantai Barat. Pada peringkat ini, golongan yang berperanan untuk memperkenalkan reka bentuk gaya Melaka ini ialah tukang dari China yang belayar bersama Cheng Ho dan pelayar dari Jawa yang datang singgah ke Melaka. ${ }^{38}$ Kenyataan tersebut membuktikan bahawa masjid rasmi kesultanan Melayu itu mempunyai ciri-ciri

masyarakat peranakan Cina ini adalah agama Islam, namun begitu setelah Eropah melancarkan serangan secara besar-besaran ke atas negara Islam, ramai yang telah memeluk ajaran kristian termasuklah cina peranakan dan sehingga akhir abad ke-15 M, dianggarakan 7400 orang telah menukar kepercayaan kepada kristian dan mereka itu terdiri daripada orang Cina dan India. Sila lihat L.P. Thomaz, "The Indiant Merchant Communities in Mallaca Under the Portuguese Rule" dalam Indo-Portuguese History: Old Issues, New Question, ed. T. R. de Souza (New Delhi: Concept Publishing, 1985), 65. Kesan penjajahan telah menyebabkan masyarakat Melayu keluar menetap di kawasan luar bandar yang kemudianya menyebabkan perkembangan agama Islam tidak berkembang dan dipengaruhi oleh unsur-unsur tahyul. Sila lihat M.A. Rauf, $A$ Brief History of Islam with Special Reference to Malaya (Kuala Lumpur: Oxford University Press, 1946), 92-93. Akibat daripada kemerosotan penyebaran Islam, ramai masyarakat peranakan Cina yang pada asalnya adalah Muslim telah kembali kepada agama asal dan ada yang menganut kristian, manakala ramai perempuan Melayu yang berkahwin dengan lelaki peranakan menjadi murtad kerana pendaftar nikah cerai dijalankan oleh pegawai Inggeris. Pada pandangan mereka penganut agama kristian adalah golongan elit jika dibandingkan dengan masyarakat Melayu yang berpegang dengan ajaran Islam adalah lemah dan dijajah. Sila lihat Haji Dusuki bin Haji Ahmad, Islam di Malaysia: Kebangkitan dan Masa Depan (Petaling Jaya: Pustaka al-Hilal, 1980), 14-15.

${ }^{35}$ Ezrin Arbi, Sejarah Perkembangan Senibina di Malaysia (Kuala Lumpur: Kementerian Kebudayaan dan Sukan, 1975), 4-5.

${ }^{36}$ Mohd Jamil bin Mukmin, Melaka Pusat Penyebaran Islam di Nusantara, 88.

${ }^{37}$ Armando Cortesao, The Suma Oriental of Tom Pires, 249-250.

${ }^{38}$ Bruce Allan, Notes on Early Mosques of the Malaysian Peninsula, 71. 
binaan dari China kerana Masjid Agung Demak ini turut menerima pengaruh ciri binaan dari China dan Cheng Ho adalah individu yang bertanggungjawab dalam memperkenalkan ciri binaan ini.

Kepesatan pembangunan masjid di setiap lokasi persinggahan juga berlaku atas sokongan maharaja China beragama Islam yang menggalakkan penyebaran dakwah terutamanya sewaktu pemerintahan Maharaja Hsuang Tse. Atas seruan dakwah ini juga setiap kali pelayaran Cheng Ho ke Asia Tenggara, beliau akan menyebarkan agama suci ini serta mendirikan masjid di kawasan yang diziarahinya. ${ }^{39}$ Justeru, setiap pelayaranya beliau membawa bersama bahan binaan dan pelan reka bentuk seni bina dari China. ${ }^{40}$ Pada tahun $1409 \mathrm{M}$, Cheng Ho dikatakan telah membawa bersama barangan yang digunakan untuk aktiviti pembinaan seperti jubin bumbung dan jubin ini direka khas untuk menampung bumbung istana raja Melayu. ${ }^{41}$ Menurut Lamprey jubin-jubin yang digunakan pada peringkat awal untuk tujuan pembangunan sememangnya dibawa khusus dari China. ${ }^{42}$ Menurut Hwang Chung, seorang penulis sejarah yang menulis berkenaan pelayaran di Melaka pada tahun 1537, sebahagian besar pembangunan yang terdapat di Melaka iaitu istana dan masjid telah dibangunkan mengikut reka bentuk dari China yang diusahakan oleh Cheng Ho. ${ }^{43}$

Pertukangan Cina dalam reka bentuk masjid di Melaka menjadi lebih hebat apabila Kaisar Cheng Le iaitu seorang pemerintah Muslim dilantik sebagai maharaja pada akhir abad ke$14 \mathrm{M}$. Baginda telah memperkenalkan beberapa ciri utama reka bentuk Cina ke Melaka dan negeri ini telah menyerap reka bentuk bangunan dari China ini dengan begitu baik sekali. Reka bentuk

${ }^{39}$ Sumanto al-Qurtuby, Arus Cina Islam Jawa (Jogjakarta: Inspeal Ahimsakarya, 2003), 117-118.

${ }^{40}$ David G Kohl, Malaysia's Architectural Heritage: Indentification Appreciation and Preservation (International Conference on Urban Conservation \& Planning, Pulau Pinang, 23-24 Jun 1986), 2-3.

${ }^{41}$ F.J Moorehead, A History of Malaya and Her Neighbours (London: Longmans, 1957), 123-125.

${ }^{42}$ M.B Lamprey, On Chinese Architecture (t.tp.: t.p., 1867), 157-176.

43 Alexender Wain, "Chinese Muslims and the Conversation of Mallaca to Islam" (prosiding, International Proceeding of Economic Development and Research (IPEDR), the University of Oxford 2012), 51:5. 
masjid yang berbentuk segi empat tepat telah dikembangkan fungsinya dan dinding bangunan masjid digantikan dengan batubata. Bumbung berlapis ditambah dengan seramik Cina sebagai pelindung bangunan masjid dan mahkota atap pula diperkenalkan di puncak bumbung sebagai suatu ciri baru. Ciri-ciri dan bentuk masjid gaya Melaka ini mempunyai persamaan dengan pagoda di China dan dikembangkan secara meluas di seluruh kepulauan Melayu. ${ }^{44}$

Perkembangan reka bentuk seni bina Cina ini juga berkembang apabila Puteri Hang Li po dibawa ke Melaka oleh Cheng Ho untuk dikahwinkan dengan Sultan Mansur Syah pada 1426 M. Kedatangan puteri ini bersama 500 orang pengikutnya telah memeluk ajaran Islam dan ditempatkan di Bukit China menyebabkan jumlah masyarakat Cina bertambah ramai di Melaka. Migrasi ini turut membawa bersama mereka bentuk dan struktur seni bina mereka yang tersendiri ${ }^{45}$ dan binaan tersebut dipraktikan ke dalam pembinaan bangunan-bangunan yang didirikan di Melaka. ${ }^{46}$

Menurut Tom Pires, sebuah masjid telah dibangunkan atas perintah Sultan Mansur Syah di Melaka. ${ }^{47}$ Pembangunan masjid ini adalah bertujuan untuk memberi kemudahan kepada masyarakat Cina Muslim bagi menjalani ibadat dan sudah tentu masjid ini dibangunkan mengikut kehendak masyarakat Cina ini

${ }^{44}$ Ken Yeang, Architecture of Malaysia (Kuala Lumpur: Pepin Press, 1992), 119.

${ }^{45}$ Rombongan yang datang bersama puteri Cina tersebut kebanyakannya menetap di kawasan bukit China dan menetap di sepanjang sungai melintasi kubu kota A Famosa. Di bawah pemerintahan Portugis, masyarakat Cina menetap di kawasan Tengkera. Selain daripada masyarakat Cina dari Fukien, pedagang-pedagang asing yang bukan berbangsa Cina juga turut menetap di kawasan tersebut. Antara nama tempat yang diletakkan perkataan Cina adalah seperti Parit China dan Gate of the Chinese. Sila lihat F.J Moorehead, A History of Malaya and Her Neighbours (London: Longmans, 1957), 125.

46 Aktiviti pembangunan oleh masyarakat Cina tidak begitu pesat pada peringkat awalnya sehinggalah kedatangan British ke Melaka. Oleh itu kesan pengaruh pertukangan Cina ini jelas boleh dilihat melalui dua fasa utama iaitu sebelum kedatangan British dan selepas penjajahan British. Sila lihat David G Kohl, Malaysia's Architectural Heritage: Indentification Appreciation and Preservation, 3.

47 Armando Cortesao, The Suma Oriental of Tom Pires (London: Haklyut Society, 1944), 249. Lihat juga Amelia Fauzia, Faith and the State: a History of Islamic Philantrophy in Indonesia (Indonesia: Bill's Southeast Asia Library), 68. 
bersesuaian dengan budaya mereka. Namun begitu, masjid-masjid yang dibangunkan Melaka sewaktu zaman kegemilangan kesultanan Melayu Melaka telah dimusnahkan oleh Portugis sewaktu melakukan penjajahan ke atas negeri itu. ${ }^{48}$ Walau bagaimanapun prototaip masjid ini masih dijadikan panduan bagi membina masjid-masjid selepas Portugis mengalami kejatuhan pada $1641 \mathrm{M}^{49}$

Pembangunan masjid di Melaka kembali pesat sewaktu Melaka berada di bawah taklukan Belanda (1641 M). Belanda telah mengimport pekerja berbangsa Cina dari Batavia (Jakarta) melalui Syarikat Hindia Timur yang berpusat di Indonesia bagi membantu proses perkembangan ekonomi dan pertukangan di Melaka. ${ }^{50}$ Kebanyakan orang Cina yang dijemput ke Melaka berasal dari Guangdong dan mempunyai kemahiran dalam bidang pertukangan kayu dan batu dan bekerja sebagai tukang-tukang bangunan dan tukang kayu. ${ }^{51}$ Mereka juga merupakan tukang pertama yang mengusahakan dan menggunakan batu bata dalam binaan bangunan. ${ }^{52}$

Sehubungan itu, pembangunan masjid dilihat berlaku dengan pesat dan hasilnya terdapat tiga buah masjid utama yang dibangunkan dengan bantuan orang Cina iaitu Masjid Tengkera, Masjid Kg. Hulu dan Masjid Kg.Keling. Reka bentuk bangunan masjid memiliki persamaan dengan Masjid Agung Demak dan dihiasi dengan motif dan ornamentasi Cina yang menarik. Terdapat hampir $46 \%$ motif dan ornamentasi Cina yang berperanan sebagai hiasan di dalam masjid ${ }^{53}$ yang terdiri daripada motif bunga, haiwan, buah, kosmos, fenomena dan geometri. Pengaplikasian motif-motif ini di dalam tiga buah masjid yang

${ }^{48}$ Suhaila Abdullah (Pensyarah Kanan di Scholl of Humanities, Universiti Sains Malaysia), dalam temubual bersama penulis, 5 Julai 2013.

${ }^{49}$ Hamka, Sejarah Umat Islam (Kuala Lumpur: Pustaka Antara, 1980), 447.

${ }^{50}$ Sarnia Hayes Hoyt, Old Mallaca (London: Oxford University Press, 1996), 24.

${ }^{51}$ Samuel Hartono Handinoto, "Pengaruh Pertukangan Cina pada Bangunan Mesjid Kuno di Jawa Abad 15-16," Dimensi Teknik Arsitektur 35, no. 1. (2007), 29.

52 Andaya Barbara Watson, A History of Malaysia (United Kingdom: MacMilan, 1983), 207.

${ }^{53}$ Ros Mahwati Ahmad Zakaria dan Nik Hassan Shuhaimi, "Motif Hiasan Tiga Buah Masjid Tua Abad ke-18 di Melaka" (makalah, World Congress For Islamic History And Civilization, Peringkat Antarabangsa, 10-11 Oktober 2011), 80 . 
dibangunkan di bawah penjajahan Belanda ini membuktikan pembabitan masyarakat Cina di dalam proses pembangunan masjid di Melaka.

Gambar 3: Motif Ekor Layang-layang di Masjid Tengkera

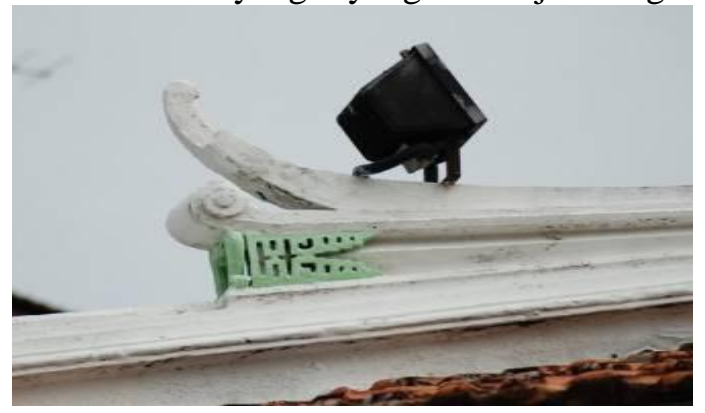

Gambar 4: Kaligrafi Cina pada Bumbung Masjid Kg. Keling yang bermaksud Kegembiraan Berganda

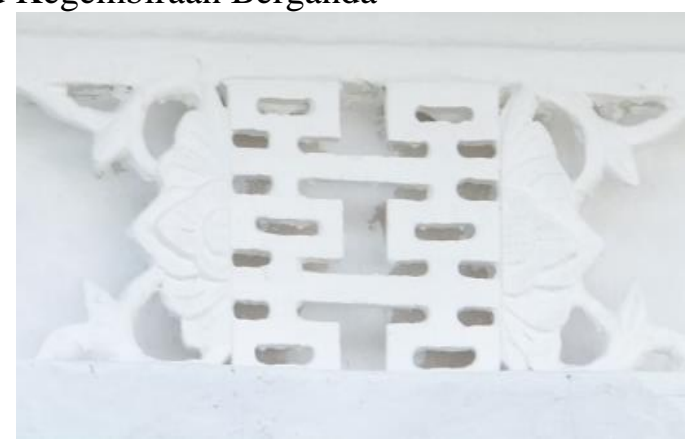

Gambar 5: Motif Tapir di sisi Mimbar Masjid Tengkera

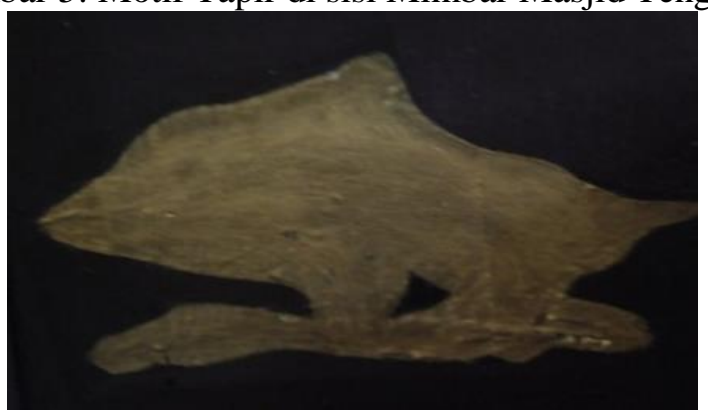


Pada peringkat awal pembinaan masjid di Nusantara, masjidmasjid didirikan mengikut rumah pembesar dan pemerintah. Keadaan ini tidak membezakan di antara rumah ibadat dan kediaman pemerintah tetapi hanya membezakan masjid dengan rumah penduduk tempatan. Walaupun masjid dibangunkan semewah rumah kediaman pemerintah, tetapi masih tidak menampilkan identiti sebuah masjid yang mempunyai bentuk bangunan khusus yang menzahirkan masjid umat Islam. Sehubungan itu, kehadiran pertukangan Cina ke Nusantara telah memperkenalkan beberapa aspek seni bina yang akhirnya diserap sebagai komponen yang lazimnya perlu ada pada setiap masjid yang dibangunkan. Masjid-masjid yang dibina atas kerjasama Cheng Ho dan masyarakat Cina yang berhijrah ke Nusantara merupakan sumbangan besar kepada pembentukan masjid di Nusantara. Ini kerana terdapat beberapa komponen utama yang diperkenalkan di China telah diserap dalam pembinaan masjid di Nusantara. Masjid berbumbung meru ini menjadi identiti utama bagi masjid yang terdapat di Nusantara serta ianya tidak ditemui di negara-negara Barat ataupun Timur Tengah. Setiap daripada warisan sejarah ini perlu dipelihara supaya warisan yang ada pada hari ini tidak hilang pada masa hadapan, kerana sesuatu yang telah hilang tidak dapat dikembalikan seperti sedia ada. Ketaksuban masyarakat Islam di Nusantara dan Malaysia khususnya terhadap bumbung kubah bawang hampir melenyapkan identiti asal masjid yang menggunakan bumbung meru. Hal ini terjadi disebabkan kurang kesedaran terhadap sejarah dan terlalu suka dengan kemodenan dan sesuatu yang baru. Kesan daripada sikap ini telah menyebabkan banyak masjid-masjid yang asalnya dibangunkan dengan gaya tradisi ini diruntuhkan dan digantikan dengan masjid baru yang moden dan berkubah bawang.

\section{Penutup}

Pelayaran Cheng Ho ke seluruh Nusantara telah memberikan impak besar kepada pembentukan reka bentuk masjid yang mempunyai unsur Cina. Reka bentuk yang diperkenalkan telah meninggalkan kesan dengan pembentukan masjid yang menjadi identiti masyarakat Islam di Nusantara. Masjid Agung Demak yang dibangunkan sekitar tempoh pelayaran Cheng Ho ini telah menjadi pelan contoh kepada tukang untuk mendirikan masjid di 
Melaka dan pelan ini telah digunakan sebanyak dua kali iaitu pembinaan masjid pada fasa pertama sekitar abad ke-15 M, tetapi musnah disebabkan penjajahan Portugis. Fasa kedua, iaitu pada abad ke-18 M, Belanda mula membuka ruang kepada masyarakat tempatan untuk mengamalkan ajaran agama dan membantu proses pembangunan masjid di Melaka.

Walaupun golongan pedagang dan golongan Cina Muslim yang datang belayar bersama Cheng Ho pada awal kurun ke-14 M ada menyumbangkan pengaruh besar dalam seni bina masjid, namun mereka tidak memainkan peranan besar dalam bidang dakwah Islamiah. Ini kerana kurangnya usaha dalam mengajak dan menyeru masyarakat tempatan yang menetap di Melaka untuk memeluk ajaran Islam. Pengislaman masyarakat tempatan di Melaka adalah hasil daripada usaha keras para pendakwah yang datang dari negara Arab terutamanya peranan golongan masyarakat Hadrami dalam usaha penyebaran ajaran Islam. Peranan dakwah Cheng Ho lebih jelas sumbangannya di Jawa, Semarang dan Gedung Batu. Setiap kawasan yang diziarahi akan disampaikan seruan dakwah dan dibina masjid serta penempatan untuk orang Cina.

\section{Bibliografi}

Allan, Bruce. "Notes on Early Mosques of the Malaysian Peninsula." Journal of the Malaysian Branch of the Royal Asiatic Society 69, part 2, no. 271 (1996).

Amelia Fauzia. Faith and the State: a History of Islamic Philantrophy in Indonesia. Indonesia: Bill's Southeast Asia Library, t.t.

Buyong Adil. The History of Mallaca: During the Period of the Malay Sultanate. Kuala Lumpur: Dewan Bahasa dan Pustaka, 1974.

Cortesao, Armando. The Suma Oriental of Tom Pires. London: Haklyut Society, 1944.

Dusuki Haji Ahmad. Islam di Malaysia: Kebangkitan dan Masa Depan. Petaling Jaya: Pustaka al-Hilal, 1980.

Ezrin Arbi. Sejarah Perkembangan Senibina di Malaysia. Kuala Lumpur: Kementerian Kebudayaan dan Sukan, 1975. 
Graaf, H.J. de dan Th. Pigeaud, Th. G. Cina Muslim di Jawa Abad $x v$ dan xvi antara Historisitas dan Mitos, ed. M.C Ricklefs. Jakarta: PT. Tiara Wacana Yogya, 1998.

Graaf, H.J. de dan Th. Pigeaud, Th. G. Chinese Muslims in Java in the 15th and 16th centuries: the Malay Annals of Semarang and Cerbon, ed. M.C Ricklefs. Melbourne: Monash University, 1984.

Groeneveldt, W.P. Notes on the Malay Archipelago and Mallaca Compilled from Chinese Sources. Jakarta: C.V. Bhratara, 1876.

Goodrich, L. Carrington. A Short History of the Chinese People. Britain: Allen \& Unwin LTD, 1957.

Hamka. Sejarah Umat Islam. Kuala Lumpur: Pustaka Antara, 1980.

Hoyt, Sarnia Hayes. Old Mallaca. London: Oxford University Press, 1996.

Ken Yeang. Architecture of Malaysia. Kuala Lumpur: Pepin Press, 1992.

Kohl, David G. Chinese Architecture in the Strait Settlements and Western Malaya. Hong Kong: University of Hong Kong, 1978.

Kohl, David G. Malaysia's Architectural Heritage: Indentification Appreciation and Preservation. International Conference on Urban Conservation \& Planning, Pulau Pinang, 23-24 Jun 1986.

Kong Yuanzhi. Pelayaran Zheng He dan Alam Melayu. Bangi: Penerbit Universiti Kebangsaan Malaysia, 2000.

Kong Yuanzhi. Muslim Tionghoa Cheng Ho: Misteri Perjalanan Muhibah di Nusantara. Jakarta: Pustaka Populer Obor, 2000.

Lamprey, M.B. On Chinese Architecture. T.tp.: t.p., 1867.

Liang Liji. Hubungan Empayar Melaka-Dinasti Ming Abad Ke 15. Bangi: Penerbit Universiti Kebangsaan Malaysia, 2009.

Liang Liji. "Jejak Langkah Sejarah Hubungan Persahabatan dan Diplomasi antara Melaka dan China, Kajian Komparatif Berdasarkan Karya Agung Melayu Sulalat al-Salatin dan KitabKitab Sejarah Lama China." Makalah, Karya Agung Melayu Sulalat al-Salatin dan Hikayat Hang Tuah, Persidangan Antarabangsa, Institut Kajian Sejarah dan Patriotisme Malaysia, Melaka, 2011.

M.A. Rauf. A Brief History of Islam with Special Reference to Malaya. Kuala Lumpur: Oxford University Press, 1946. 
Moorehead, F.J. A History of Malaya and Her Neighbours. London: Longmans, 1957.

Purcell, Victor. The Chinese in Malaya. London: Oxford University, 1967.

Ros Mahwati Ahmad Zakaria dan Nik Hassan Shuhaimi. "Motif Hiasan Tiga Buah Masjid Tua Abad ke-18 di Melaka." Makalah, World Congress for Islamic History and Civilization, Peringkat Antarabangsa, 10-11 Oktober 2011, 80.

Samuel Hartono Handinoto. "Pengaruh Pertukangan Cina pada Bangunan Mesjid Kuno di Jawa Abad 15-16," Dimensi Teknik Arsitektur 35, no. 1. (2007): 29.

Slametmuljana. A Story of Majapahit. Singapore: Singapore University Press, 1976.

Sumanto al-Qurtuby. Arus-Cina-Islam-Jawa. Jogjakarta: Inspeal Ahimsakarya Press, 2003.

Ta Ta Sen. Cheng Ho and Islam in Southeast Asia. Singapore: ISEAS Publishing Institute of Southean Asian Study, 2009.

Teo Kok Seong. "Bukti dan Pengaruh Cina Muslim di Nusantara." Makalah, Seminar Sumbangan Orang Cina Terhadap Perkembangan Islam di Nusantara Peringkat Kebangsaan, 24-26 Ogos 2006.

Thomaz, L.P. "The Indiant Merchant Communities in Mallaca Under The Portuguese Rule" dalam Indo-Portuguese History: Old Issues, New Question, ed. T. R. de Souza. New Delhi: Concept Publishing, 1985.

Vlatseas, S. A History of Malaysian Architecture. Singapore: Longman Singapore Publisher, 1990.

Wain, Alexender. "Chinese Muslims and The Conversation of Mallaca to Islam." Prosiding, International Proceeding of Economic Development and Research (IPEDR), the University of Oxford, v.51, 2012, 5.

Watson, Andaya Barbara. A History of Malaysia. United Kingdom: MacMilan, 1983.

Wheatley, Paul. The Golden Khersonese. Kuala Lumpur: Penerbit Universiti Malaya, 2010.

Yeang, Ken. Architecture of Malaysia. Kuala Lumpur: Pepin Press, 1992. 
Syaimak, Abdullah, Nurhafizah dan Nabilah, Pengaruh Pelayaran Cheng Ho 